\title{
Characterization of the physical education environment and practice in public schools
}

\section{Caracterização do ambiente e da prática da educação física em escolas públicas}

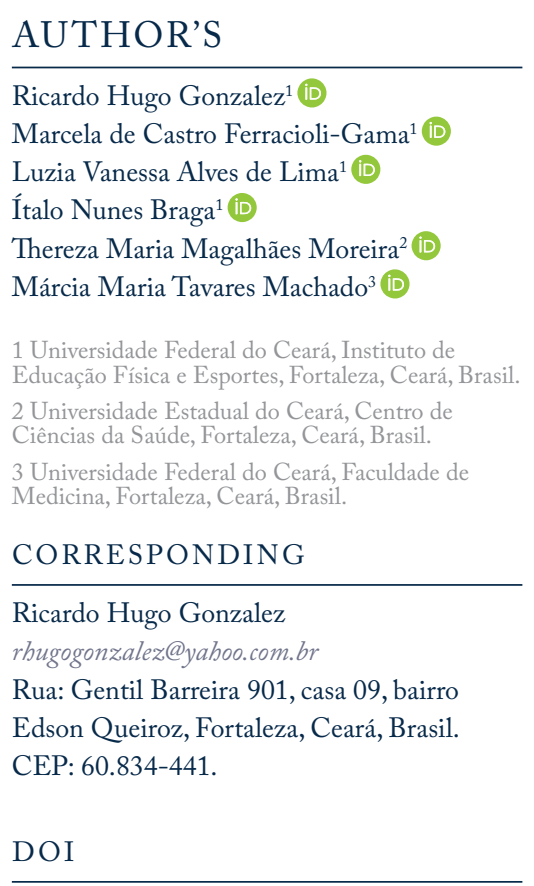

$10.12820 /$ rbafs. $26 \mathrm{e} 0187$

\begin{abstract}
This cross-sectional, stratified, random sample study aimed to identify the school environment for teaching and engaging in physical education in elementary public schools. An inventory assessment was made and interviews were held with school managers in 12 teaching units in Fortaleza, Ceará, Brazil. The data obtained were categorized as follows: lesson availability and frequency, recess, extracurricular activities, facilities, and installations in place. The descriptive analysis used absolute and relative frequencies values. The results showed that all schools involved in the study provide two weekly physical education classes. None of the schools engaged in the development of recreational activities during recess. Data showed that $75 \%$ of schools participating in the study provide free extracurricular activities, among which futsal was the most popular (58.3\%). Also, $75 \%$ of schools had indoor sports facilities, whereas some schools did not have adequate space to hold classes. In the group of schools with facilities, $90 \%$ had crossbars and $70 \%$ had at least one type of floor markings for sports such as futsal, basketball, and volleyball. Only one school had a recreational room, patio, and a green area. We concluded that the results point to a favorable direction for teaching and engaging in physical education in schools. We discussed how an adequate environment in schools helps students make better lifestyle choices and provides teachers with the opportunity to fully develop their classes and promote student's health.
\end{abstract}

Keywords: School environment; Physical infrastructure; Physical education at school.

RESUMO

O objetivo deste estudo foi identificar o ambiente escolar disponível para o ensino e a prática de educação física em escolas públicas de ensino fundamental. Trata-se de estudo transversal com amostra aleatória e estratificada. Foi realizada uma avaliação do inventário e realizadas entrevistas com os diretores de 12 escolas de Fortaleza, Ceará, Brasil. Os dados obtidos foram categorizados como: disponibilidade e frequência das aulas, desenvolvimento de atividades no recreio, atividades extracurriculares oferecidas, instalaçóes e acesso às mesmas. Os dados foram analisados através das frequências absolutas e relativas descritivas. Os resultados mostraram que todas as escolas envolvidas no estudo oferecem duas aulas de educação física por semana. Nenhuma das escolas desenvolve atividades recreativas durante o recreio. Os dados mostraram que $75 \%$ das escolas participantes do estudo oferecem atividades extracurriculares gratuitas. Entre elas, o futsal foi a opção mais popular (58,3\%). Além disso, 75\% das escolas possuíam instalaçôes esportivas internas, enquanto algumas escolas não dispunbam de espaço adequado para realizar as aulas. No grupo de escolas com instalaçôes, $90 \%$ possuiam traves e $70 \%$ tinham pelo menos um tipo de marcação para esportes no piso, como futsal, basquete ou vôlei. Apenas uma escola possuía uma sala de recreação, pátio e horta. Concluímos que os resultados apontam para uma direção favorável ao ensino e à prática da educação física nas escolas. Nós discutimos como um ambiente adequado nas escolas ajuda os alunos a fazer melhores escolhas de estilo de vida e fornece ao professor a oportunidade de desenvolver completamente suas aulas e promover a saúde dos alunos.

Palavras-chave: Ambiente escolar; Infraestrutura física; Educação física escolar.

\section{Introduction}

A school with physical education facilities and an adequate amount of equipment empowers teachers to take full action in guiding this comprehensive part in the students' development, which encourages scholars to participate more actively in the classes, achieves the educational objectives, and makes physical activity more attractive to the students ${ }^{1}$.

Regular physical activity has several benefits. In broad terms, such benefits are expanded if started at a very young age and promote physical well-being ${ }^{2}$. It is crucial to consider the physical education class infrastructure, the school environment model, playtime quality, and extracurricular activities available to children ${ }^{1}$ for developing this activity at school.

Spaces that most commonly contribute the most to children's academic development are libraries or reading rooms, sports courts, and computer labs - affirms 
the Basic Education Development Index - IDEB 3 . Unfortunately, many Brazilian public schools are poorly equipped ${ }^{4}$. A study also showed that $35 \%$ of Latin American primary education schools do not have adequate spaces for physical education classes ${ }^{5}$. The inadequate structures or equipment may become a hurdle to the good progress of physical education classes ${ }^{6}$.

It is fundamental to understand the obstacles and opportunities and studies on school conditions in different Brazilian regions and scientific evidence that points out the importance of a dedicated physical education environment are highly relevant in producing crucial changes as they allow an understanding of the challenges and opportunities of teaching and learning obstacles and opportunities ${ }^{1}$. This study aimed to identify the school facilities and the infrastructure dedicated to teaching and engaging in physical education in the public elementary schools of Fortaleza, Ceará, Brazil.

\section{Method}

The public education network of Fortaleza ${ }^{7}$ consists of 289 elementary schools, and the city's administrative management is subdivided into six Regional Executive Secretariats (SER). This is a cross-sectional, stratified, and sample-based study. Twelve municipal primary schools (EMEF) were selected from a draw, two from each region (SER), based on the inclusion criteria of having at least 700 students. The exclusion criterion was schools non-authorized by the school principal. The study was approved by the Human Research Ethics Committee of the Federal University of Ceará under protocol CEP 1.668.466/2016 and CAAE: 53641416.9.0000.5045. The consent form was verified. This study is nested in a major study entitled "Risk behaviors in young people of a Brazilian capital of the Northeast".

The Assessment of School Environments adapted from the Lifestyle and Health research group of the Federal University of Pernambuco, Brazil ${ }^{8}$ was used to identify the aspects of interest of the study: a) physical education lessons, b) recreational activity, c) extracurricular activities, and d) school's dedicated infrastructure. In this study, the school environment refers the conditions provided for engaging in any type of physical activity - physical education infrastructure, lessons, extracurricular activities, equipment, materials, and infrastructure accessibility in unsupervised stages. Extracurricular activity refers to physical activity opportunities consistently provided by schools, which cannot be characterized as physical education curricular classes.
The Municipal Department of Education (SME) of Fortaleza, Ceará, was contacted. We presented the study's objectives and procedures and requested authorization for their implementation in elementary schools. Following consent, the SME provided us with school data (on Municipal Elementary Schools, or EMEFs). We conducted interviews with school managers to collect information on the number of students per class, the number of physical education teachers, physical education weekly classes, duration of physical education classes, physical education classes in indoor gyms, duration of recess, and any extracurricular activities. Direct observations were adopted to collect information about physical spaces at schools. These procedures were implemented in September and October 2018 by physical education undergraduates previously trained to apply the selected inventory standard. Each data was collected separately for about 30 minutes, including an interview and an environment observation.

The descriptive analysis used absolute and relative frequencies values concerning a sociodemographic data, physical education classes, recess, extracurricular activity, and dedicated infrastructure.

\section{Results}

Most schools meet the Enrollment Guidelines (Municipal Department of Education - $\mathrm{SME}^{9}$ ) regarding the maximum number of schoolchildren per elementary school class, with 20 to 25 students in the earlier years and up to 35 students in the later years. Nevertheless, $33 \%$ of the schools investigated had more students per class than recommend by the $\mathrm{SME}^{9}$.

Table 1 shows data obtained regarding the central aspects of physical education classes. All had physical education classes taught by licensed teachers.

Table 2 shows data on the recreation and physical and extracurricular activities of the participating schools. The results evidenced that all participating schools provide 2 to 3 recesses daily. However, none of them have supervised recreational activities during such recesses.

Futsal was the most prevalent extracurricular activity option, followed by volleyball and basketball. The physical education teacher is responsible for extracurricular activity in half of the schools. The other half had professional volunteers. Half of the schools have no access to the infrastructure dedicated to physical activity for schoolchildren outside physical education class time and extracurricular activities.

Such activities are performed in all schools in their 
dedicated infrastructure, which is shown in Table 3. The results evidenced that $92 \%$ of schools with sports courts or gymnasium have beams, and $70 \%$ of them have at least one floor marking for sports such as futsal, basketball, and volleyball.

Table 1 - Absolute (n) and relative (\%) frequencies of participating schools by aspects of physical education classes.

\begin{tabular}{lc}
\hline Physical Education & $\mathrm{n}(\%)$ \\
\hline Number of physical education teachers & \\
$1-3$ & $7(58.3)$ \\
$4-6$ & $5(41.7)$ \\
Physical education classes per week & \\
1 & $0(0.0)$ \\
2 & $12(100.0)$ \\
3 & $0(0.0)$ \\
Duration of physical education classes (min) & \\
$45-50$ & $8(66.7)$ \\
$51-60$ & $4(33.3)$ \\
Physical education classes in an indoor gym & $9(75.0)$ \\
\hline
\end{tabular}

Table 2 - Absolute (n) and relative (\%) frequencies of participating schools by aspects related to recess and physical/extracurricular activities.

\begin{tabular}{lc}
\hline Recess and physical/extracurricular activities & $\mathrm{n}(\%)$ \\
\hline Duration of recess & $1(8.3)$ \\
$10 \mathrm{~min}$ & $5(41.7)$ \\
$15 \mathrm{~min}$ & $6(50)$ \\
$20 \mathrm{~min}$ & $9(75.0)$ \\
Free extracurricular activities & $0(0.0)$ \\
Paid extracurricular activities & $6(50.0)$ \\
Shift-based activities & $7(58.3)$ \\
School Sports Tournament & $2(16.7)$ \\
Extracurricular activity recreation & $7(58.3)$ \\
Extracurricular activity futsal & $3(25.0)$ \\
Extracurricular activity volleyball & $0(0.0)$ \\
Extracurricular activity dance & $1(8.3)$ \\
Extracurricular activity handball & $3(25.0)$ \\
Extracurricular activity basketball & $1(8.3)$ \\
Extracurricular activity other &
\end{tabular}

Table 3 - Absolute (n) and relative (\%) frequencies of participating schools by physical spaces, according to inventory investigated.

\begin{tabular}{lc}
\hline Physical space & $\mathrm{n}(\%)$ \\
\hline Sports gym & $9(75.0)$ \\
Roof-covered sports court & $1(8.3)$ \\
Recreational room & $1(8.3)$ \\
Playground & $0(0.0)$ \\
Courtyard & $1(8.3)$ \\
Garden & $1(8.3)$ \\
Green area & $1(8.3)$ \\
Swimming pool & $0(0.0)$ \\
\hline
\end{tabular}

\section{Discussion}

This study aimed to identify the school environment for teaching and engaging in physical education in elementary public schools. The authors will discuss and analyze the four variables of the instrument that responded directly to the objectives of the study, namely, a) physical education lessons, b) recess, c) extracurricular activities, and d) dedicated school infrastructure:

\section{Physical education classes}

One positive aspect observed in this study is that all participating schools provide physical education classes conducted by licensed physical education teachers. Law No. 9.394/96 - LDB (Law on the Guidelines and Bases of National Education) establishes that physical education must be integrated into the school's pedagogical proposal as a compulsory curricular component of elementary education ${ }^{10}$.

Attending physical education classes has been associated with lower exposure to sedentary behaviors, higher physical activity levels, greater participation in sports, healthy eating habits, and a lower likelihood of consuming legal and illegal drugs ${ }^{11}$. In this sense, a school environment is a place for children and adolescents' possible engagement in physical activities. In severe social vulnerability cases, this becomes the only opportunity to experience physical group interaction in their lives. Schools can fully grant these benefits only when they have the primary conditions to run such classes: physical spaces conducive to activities and time within the proposed curriculum ${ }^{12}$.

It should be highlighted that $25 \%$ of the participating schools do not carry out physical education classes in a roof-covered sports facility. Considering the northeast Brazilian region's climate - hot and humid - the physical activity conditions in the open environment can be poor and sometimes harmful to the health of students and teachers. In Brazil, $46.8 \%$ of public schools are not equipped with sports courts ${ }^{13}$. Some authors argue that public schools with more extensive or better physical structures do not necessarily influence adolescents' engagement in physical education during school play and physical education classes ${ }^{14}$. However, school spaces with favorable conditions can benefit activities planned by teachers and, consequently, increase the students' level of physical activity.

The Fortaleza Municipal Education Plan 2015$2025^{15}$ includes a strategy to ensure the functioning of proper learning environments to the school's work to 
expand the educational possibilities through playful, motor skills, and practical activities with the availability of qualified teachers in these spaces. However, some schools may not guarantee the fulfillment of these objectives because they have not yet been included in this planned strategy.

Regarding the volume of physical education classes and many Brazilian schools (The Brazilian Institute of Geography and Statistics - IBGE ${ }^{16}$ ), the schools investigated provided two weekly physical education classes with a duration of $45-50$ minutes. This time is only $8 \%$ of the time that schoolchildren stay in school during the week. Therefore, we suggest increasing the volume of weekly physical education classes. Schoolchildren spend more time on moderate-to-vigorous physical activity (MVPA) on days that include physical education classes than on days without them ${ }^{17}$. Enrollments in the national primary education system have grown in recent decades. Thus, it is a challenge for public education policies to ensure access to knowledge and a minimum infrastructure for all schoolchildren's learning.

\section{Recess}

Recess is essential for schoolchildren to break out of classroom obligations and increase their daily physical activity ${ }^{1,18}$. During this break, children are free to join in or leave play situations as they please ${ }^{19}$. Moreover, it has been considered a break from the teacher's teaching activity and students' time to release locked energy, rest, or snack. Sometimes recess is devalued by school management through neglect or for economic reasons. However, this time is part of education and cannot be disregarded.

This study evidenced that the schools investigated provide two to three daily recesses, which can be positive with some physical activity level by schoolchildren $^{1,20}$ and social relationships. Students can experiment with new social strategies due to the playful nature of recess ${ }^{19}$, which provides better developmental conditions. Therefore, this time should also be planned and organized. However, no schools participating in this study were designing supervised physical activities for the recess. Increased physical activity positively affects students' satisfaction with school, and physically active recess contributes to a more peaceful learning environment ${ }^{21}$.

According to Morton et al. ${ }^{22}$, the school's lack of physical infrastructure meant that more physical activity opportunities could simply not be provided.
For example, if the environment in which recess takes place has no interactive material or restricted mobility, children do not interact with their bodies and invent situations, as opposed to when the environment has dedicated material and space, where they and this environment's rules mediate the activities.

Recess can provide daily opportunities to increase physical activity in schoolchildren ${ }^{18}$. Taking advantage of the school's physical space for engaging in physical education classes and the time allocated for recreation to carry out activities guided by licensed teachers contributes to students' development. However, schoolchildren's participation in these activities should be voluntary, considering the essential nature of recreation - time off curricular activities.

\section{Extracurricular activities}

Regular extracurricular activities are non-curricular, conducted in or out of school, and can be used as strategies to reduce negative classroom behaviors ${ }^{23}$. In this study, $75 \%$ of the schools investigated provide extracurricular physical activities - tournaments, sports, and recreational activities - to their students. These extracurricular physical activities can provide the opportunity to develop and learn about different aspects of physical education ${ }^{8}$. Also, Shulruf, Tumen, and Tolley ${ }^{24}$ have shown a positive relationship between participation in extracurricular activities, more specifically of collective sports, and improved learning. In Brazil, these actions do not occur in the long run due to the lack of efficient public policies. Not all extracurricular activities are valued equally since priority is given to mandatory academic activities.

Futsal was the most prevalent option among the extracurricular sports activities. These results are consistent with the Brazilian "football" culture, likely causing futsal to be the most popular activity in the school environment due to sports initiation or technical and tactical training ${ }^{25}$. However, some schools investigated in this study lack structures to provide extracurricular activities to schoolchildren. The National Survey of Evaluation of the "Segundo Tempo" (translated as Before/After School Hours) Program by the beneficiaries and their families carried out by the Pontifical Catholic University of Minas Gerais PUC/MG, found that as of late $2010,57 \%$ of extracurricular activities are placed outside the school environment due to the lack of adequate dedicated space for the activities planned in the Program. The availability of a sports court in schools 
and providing extracurricular physical activities are associated with increasing physical activity in young Brazilian students.

Extracurricular activities follow the dynamics of curricular activities. Concerning Brazil's public policies to promote a healthy lifestyle at school, physical activity and nutrition ${ }^{26}$ actions were implemented as of 2007. Integrated and articulated physical activities in schools and health- and education-related fields are extremely relevant. However, Prado et al. ${ }^{27}$ state that the scarce evidence on local school physical activity strategies, structures, and Brazilian policies are not updated. The opportunities for physical activity in schools are still provided with low frequency and duration to adolescents. It is crucial to alert competent authorities about this reality for future planning and implementation of these activities in the long term.

\section{Physical spaces for physical education classes}

School is an integral part of life. Individuals with this opportunity spend approximately 14 years of their lives there. Thus, it is necessary to perceive its dynamics to understand people's diverse attitudes and conduct in this environment. Nowadays, this environment assumes the role of teaching and educating and socializing. It has become the delegate of education relied on by parents and educators. As the discipline requires exploring the body in motion, the physical space is highly relevant in the implementation of class activities ${ }^{28}$. In this sense, schools must create a conducive environment to facilitate children and adolescents' comprehensive development.

When we think of physical education as a discipline in the educational curriculum, we perceive a relevance different from other disciplines. Besides dealing with body culture and health, it also contributes to the comprehensive development of the students. The physical education class environment of public schools shows a barely investigated reality in Fortaleza, despite the apparent state of emergency. Basic infrastructure is essential for the teaching practice and, consequently, for improving students' lifestyles. This discussion does not intend to justify that physical education classes can only happen with the desired environmental conditions but aims to identify the physical education class environment's condition to sensitize people about involving schoolchildren and teaching practices.

While the physical education class frequency met the minimum legal requirements, not all schools have adequate infrastructure for physical education classes and extracurricular activities. These results agree with public schools' reality in other major Brazilian cities, such as Recife (Pernambuco $)^{8}$ and Maringá (Paraná) $)^{12}$. Lack of available equipment, space, and structure may limit physical education teachers' approaches or make them even improvise spaces to overcome hardships ${ }^{28}$. Due to the specificities of physical education, the lack of materials and space hinders pedagogical proposals based on new paradigms, which are articulated with proposals for appropriating body culture, necessarily engaged in practical experience and content diversity ${ }^{29}$. Both the physical education teacher and the physical school environment are essential predictors of autonomous motivation to engage in physical education. Under current conditions, the physical education teacher often needs to adapt the curricular activity to alternative spaces and materials, to the extent that many activities fail to be realized ${ }^{30}$. The teacher's work becomes consistently stressful and discouraging as the expected curricular objectives are not achieved.

The Brazilian Educational System faces a significant challenge to address these inequalities in the country's municipalities, states, and regions. Many physical education teachers argue that the most significant obstacles are the lack of efficient public policies for investment and provision of infrastructure and material resources, and public policies for the continuous development of teachers, collective organization of pedagogical work, legitimacy of Physical Education, and participation of the students and their families ${ }^{12}$.

We underscore that we do not intend to evaluate the quality of the school's infrastructure. We are only proposing a reflection on how the physical education classes are provided to these students. These classes are provided twice a week (with a duration of two hours), and half of them are theoretical. Thus, these students have only one weekly hour of physical activity, which is significantly short to enhance physical fitness and motor skills.

We conclude by saying that the results point to a favorable direction for the practice and teaching of physical education in the schools investigated, considering that all schools have physical education teachers conducting classes twice a week, and most of them have indoor sports facilities. More than half provide recesses, extracurricular activities, or sports training. The purchase of dedicated material, the construction and maintenance of infrastructure, such as sports 
courts, drinking water fountains, bathrooms, and dressing rooms for the physical education discipline, and an increased provision of extracurricular activities are the goals to be achieved by the public sector of elementary schools of Fortaleza, Ceará, Brazil. We suggest an increase in the volume of weekly physical education classes. Further studies establishing the relationship between the school environment and physical education classes should be conducted considering the differences between schools to expand the discussion on the topic. Studies of this nature will compare conditions in different Brazilian locations, observing the relationship between such conditions and the students' development and performance.

\section{Conflict of interest}

The authors declare no conflict of interest.

\section{Author's contributions}

Gonzalez RH participated in the design of the manuscript, analysis, and interpretation of the data. Ferracioli-Gama MC wrote the manuscript and critically reviewed the content. Lima LVA participated in the planning, data collection, and writing of the manuscript. Braga IN participated in the data collection and writing of the manuscript. Moreira TMM participated in the writing of the manuscript and critical review of the content. Machado MMT participated in the planning, coordination, and critical review of the manuscript.

\section{Acknowledgments}

The authors are grateful to the Municipal Education Secretariat of Fortaleza for facilitating our contact with schools.

\section{References}

1. Mélo EN, Barros M, Hardman C, Siqueira M, Wanderlei Júnior R, Oliveira E. Associação entre o ambiente da escola de educação infantil e o nível de atividade física de crianças pré-escolares. Rev Bras Ativ Fís Saúde. 2013;18(1):53-62.

2. Altavilla G, Di Tore PA. Physical education during the first school cycle: a brief social psych pedagogical summary. J Phys Educ. 2016;16(2):340-4.

3. Bonamino A, Lima NCM. Aspectos da gestão escolar e efeitos no desempenho dos alunos dos anos iniciais do ensino fundamental. In Martins AM et al. (eds.). Políticas e gestão da educação: desafios em tempos de mudanças. Campinas: Autores Associados. 2013, p. 92-117.

4. Tani G, Basso L, Silveira SR, Correia WR, Corrêa UC. O ensino de habilidades motoras esportivas na escola e o esporte de alto rendimento: discurso, realidade e possibilidades. Rev Bras Educ Fís Esporte. 2013;27(3):507-18.

5. Duarte J, Gargiulo C, Moreno M. School infrastructure and learning in Latin American elementary education: an analysis based on the SERCE. [s.1.]: Inter-American Development Bank, Education Division (SCL/EDU). 2011.
6. Silva AAP, Lopes AAS, Prado CV, Hino AAF, Reis RS. Características do ambiente físico e organizacional para a prática de atividade física nas escolas de Curitiba, Brasil. Rev Bras Ativ Fís Saúde. 2018;23:e0027.

7. Fortaleza. Prefeitura Municipal. Rede de ensino: ensino fundamental. 2019. Retrieved from <http://educacao. fortaleza.ce.gov.br/index.php/rede-de-ensino/ensinofundamental>.

8. Tenório MCM, Tassitano RM, Lima MC. Conhecendo o ambiente escolar para as aulas de Educação Física: existe diferença entre as escolas? Rev Bras Ativ Fís Saúde. 2012;17(4):307-13.

9. Secretaria Municipal de Educação. Diretrizes: matrícula 2016. Fortaleza. 2015. Retrieved from <http://www.sme. fortaleza.ce.gov.br/educacao/files/2015/DIRETRIZES_ MATRICULA_2015_16_01.pdf\&gt.>

10. Brasil, Ministério da Educação. Secretaria de Educação Básica, Secretaria de Educação Continuada, Alfabetização, Diversidade e Inclusão, Conselho Nacional da Educação. Diretrizes Curriculares Nacionais Gerais da Educação Básica/ Ministério da Educação. Brasília: MEC, SEB, DICEI. 2013.

11. Prazeres Filho A, Mendonça G, Souza Neto JM, Tassitano RM, Silva ABP, Farias Júnior JC. Attendance in Physical Education classes and associated factors among high school students. Rev Bras Ativ Fís Saúde. 2019;24:e0083.

12. Magalhães CHF, Martineli TAP. Soluções formais no enfrentamento dos problemas da prática escolar: o estranhamento dos professores de educação física escolar. Motrivivência. 2011; 36:214-35.

13. Brasil, Ministério da Educação. Notas estatísticas censo escolar 2016. Brasília: MEC. 2017.

14. Dias AF, Lemes VB, Brand C, Mello JB, Gaya AR, Gaya ACA. Associação entre estrutura da escola com a atividade física na aula de educação física e no recreio. Rev Bras Cineantropom Desempenho Hum. 2017;19(2):164-73.

15. Fortaleza. Plano Municipal da Educação de Fortaleza (2015 - 2025). Diário Oficial do Município n¹5.549. 2015.

16. Instituto Brasileiro de Geografia e Estatística. Pesquisa nacional de saúde escolar. Rio de Janeiro: Instituto Brasileiro de Geografia e Estatística. 2016.

17. Aljuhani O, Sandercock G. Contribution of physical education to the daily physical activity of schoolchildren in Saudi Arabia. Int J Environ Res Publ Health. 2019;16(13):1-12.

18. Khorana P, Koch PA, Trent R, Gray HL, Wolf RL, Contento IR. The effects of wellness in the schools (WITS) on physical activity during recess in New York City public schools. Phys Activ Health. 2019;3(1):117-26.

19. Stapp AC, Karr JK. Effect of recess on fifth-grade students' time on-task in an elementary classroom. Int Electron J Elem Educ. 2018;10(4):449-56.

20. Mota J, Silva P, Santos MP, Ribeiro JC, Oliveira J, Duarte JA. Physical activity and school recess time: differences between the sexes and the relationship between children's playground physical activity and habitual physical activity. J Sports Sci. 2005;23(3):269-75.

21. Haapala HL, Hirvensalo MH, Laine K, Laakso L, Hakonen H, Lintunen T, Tammelin TH. Differences in physical activity at recess and school-related social factors in four Finnish lower secondary schools. Health Educ Res. 2017;32(6):499-512.

22. Morton KL, Atkin AJ, Corder K, Suhrcke M, Van Sluijs EMF. The school environment and adolescent physical activity and sedentary behaviour: A mixed-studies systematic review. Obes Rev. 2016;17(2):142-58. 
23. Balyer A, Gunduz Y. Effects of structured extracurricular facilities on students' academic and social development. Procedia - Social and Behavioral Sciences. 2012; 46:4803-7.

24. Shulruf B, Tumen S, Tolley H. Extracurricular activities in school, do they matter? Child Youth Serv Rev. 2008;30(4):418-26.

25. Alves FR. Fatores motivacionais para a prática do Futsal em adolescentes entre 11 e 17 anos. Rev Bras Futsal Futebol. 2015;7(27):579-85

26. Batista MDSA, Mondini L, Jaime PC. Ações do Programa Saúde na Escola e da alimentação escolar na prevenção do excesso de peso infantil: experiência no município de Itapevi, São Paulo, Brasil, 2014. Epidemiol Serv Saúde. 2017;26(3):569-78.

27. Prado CV, Farias Júnior JCD, Czestschuk B, Hino AAF, Reis RS. Physical activity opportunities in public and private schools from Curitiba, Brazil. Rev Bras Cineantropom Desempenho Hum. 2018;20(3):290-9.
28. Mota MM, Torres AL, Alves BO, Ferreira HS. Physical education in school: physical spaces and materials in a public school in Fortaleza. Motricidade. 2017;13(S1):70-5.

29. Rufino LGB, Benites LC, Souza Neto S. Os desafios para o desenvolvimento do trabalho docente na perspectiva de professores de educação física. Corporescência. 2017;21(3):55-65.

30. Rutten C, Boen F, Seghers J. How school social and physical environments relate to autonomous motivation in physical education: The mediating role of need satisfaction. J Teach Phys Educ. 2012;31(3):216-30.

\section{Quote this article as:}

Gonzalez RH, Ferracioli-Gama MC, Lima LVA, Braga IN, Moreira TMM, Machado MMT. Characterization of the physical education environment and practice in public schools. Rev Bras Ativ Fis Saúde. 2021;26:e0187. DOI: 10.12820/rbafs.26e0187 